\title{
Rancang Bangun Sistem Kendali Kecepatan Motor DC Sebagai Media Pembelajaran Praktikum Sistem Kendali Menggunakan Labview
}

\author{
Nanang Roni Wibowo ${ }^{1 *}$, Aminuddin ${ }^{2}$, Muh Niel Authar Syaputra ${ }^{3}$ \\ ${ }_{1,2,3}$ Politeknik Bosowa, Kota Makassar, Indonesia \\ *E-mail: nanangroni80@gmail.com
}

\begin{abstract}
This study determines the design and manufacture of DC motor speed control system using arduino board integrated with labview student edition software that is used as a tools for learning media in control systems engineering. The speed of the motor was measured with incremental rotary encoder 600ppr and controlled by regulated pulse width modulation (PWM) value. The controller was used proportional-integral-derivative (PID) that was implemented by using PID and Fuzzy logic toolkit from labview and also used arduino board as a data acquisition device. Interfacing between arduino and labview using NI-Visa serial. The research methods was used experimental method with the result obtained by testing each section to get transfer function. Overall test result obtained the best performance with PID parameters are $k c=0.084, t i=0.50, t d=0.0$.
\end{abstract}

Keywords :NI-VISA Serial, Arduino Uno, Incremental Rotary Encoder, Labview PID Controller.

\begin{abstract}
Abstrak
Penelitian ini menjelaskan mengenai perancangan dan pembuatan sistem kendali kecepatan motor DC dengan menggunakan Arduino Board yang terintegrasi dengan perangkat lunak Labview yang dipergunakan sebagai alat bantu media pembelajaran sistem kendali. Kecepatan motor diukur dengan menggunakan incremental rotary encoder 600ppr dan dikendalikan dengan mengatur tegangan rata-rata yang diberikan dalam bentuk pulse width modulation $(P W M)$. Pengendali yang dipergunakan adalah pengendali proportional-integral-derivative (PID) yang diimplementasikan dengan menggunakan PID and Fuzzy logic toolkit darilabview dengan arduino board sebagai perangkat akuisisi data, antarmuka antaralabview dengan arduino board menggunakan NI-VISA Serial. Metodologi penelitian yang dipergunakan adalah metode experimental dengan hasil penelitian diperoleh dengan melakukan pengujian secara bertahap terhadap masing-masing bagian untuk mendapatkan karakteristiknya. Hasil pengujian keseluruhan diperoleh performa terbaik dengan parameter $P I D$ adalah $\mathrm{Kc}=0.084, \mathrm{Ti}=0.50, \mathrm{Td}=0.0$.
\end{abstract}

Kata kunci :NI-VISA Serial, Arduino Uno, Incremental Rotary Encoder, Pengendali PID Labview.

\section{Pendahuluan}

Banyak produk motor yang memenuhi peryaratan berbeda, berupa kekuatan, kecepatan, daya, akurasi dan posisi, untuk mendapatkan hasil maksimal dari perangkat elektromekanis perlu diketahui karakteristik elektromekanis, operasi, fisik dan perilakunya dalam melakukan pengembangan model fisik dan matematik yang memungkinkan adaptasi dan kendali perangkat ini dengan persyaratan dari berbagai bidang teknik[1],[2].

Motor dc mempunyai peran penting dalam banyak aplikasi di industri. Dengan persyaratan kendali yang tinggi, motor dc dapat digunakan dalam sistem kendali kecepatan dengan presisi tinggi, seperti alat rolling mill dan lainya[3]. 
Motor DC (Direct Current) sebagai salah satu jenis aktuator sampai saat ini masih banyak dipergunakan dalam teknologi kendali baik di industri maupun di rumah tangga, kelebihan motor dc yang memiliki respon yang cepat namun masih memiliki error steady state. Kekurangan ini dapat diperbaiki salah satunya dengan menggunakan pengendali PID (Proportional - Integral - Derivative) yang mempunyai respon yang cepat sehingga sesuai jika dipergunakan untuk mengendalikan motor dc[4],[5].

Pengendali PID adalah algoritma pengendali yang umum digunakan saat ini baik di industri untuk tujuan pengendalian suatu proses, pengendali pada sistem servomekanisme dan masih banyak lagi, proses yang ada kebanyakan dipengaruhi oleh beberapa factor diantaranya : gangguan, dinamika dari proses tak linier, derau, adanya tunda waktu pengukuran dan lagging, batasan terhadap sensitivitas dan resolusi. Faktor yang merugikan tersebut dapat dikurangi dengan adanya pengendali $P I D$ dengan fleksibilitasnya[6],[7].

Labview (Laboratory Virtual Instrument) sebagai bahasa pemrograman berbasis grafis yang dikembangkan oleh perusahaan National Instruments (NI) pada tahun 1986 memiliki integrasi dengan banyak perangkat keras dan library yang dapat dipergunakan untuk aplikasi di bidang instrumentasi, pengolahan sinyal, analisa dan visualisasi data dan interkoneksi jaringan, salah satu fitur yang dapat dipergunakan dalam penelitian ini adalah adanya Toolkit untuk PID dan Fuzzy Logic serta adanya library untuk komunikasi serial dengan menggunakan Toolkit NI-VISA Serial[4],[8].

Penelitian [1] menggunakan perangkat DSPIC30F4011 yang merupakan chip khusus untuk pemrosesan sinyal digital yang mempunyai kemampuan pemrosesan operasi matematika secara cepat namun harus dibayar dengan biayanya yang besar, sedangkan dalam penelitian ini operasi matematika dilakukan di computer dengan menggunakan perangkat lunak Labview sehingga penggunaan arduino sebagai perangkat akuisisi data sudah memadai. Sedangkan penelitian [3] perangkat yang dipergunakan hanya dipergunakan untuk melakukan pengujian pengendalian kecepatan motor terhadap perubahan suhu, sedangkan pada penelitian [6] berhasil membuat pengendali PID untuk motor DC dengan biaya rendah, sistem yang dibangun sebagai alat bantu dalam proses pembelajaran dengan Arduino sebagai Platform dan library LINX yang digunakan untuk komunikasi Labview dan Arduino, kinerja sistem dievaluasi melalui hasil eksperimental dengan melakukan tuning $K p, T d$, dan $T i$ sehingga respons sistem dapat diatur [6].Penelitian yang dilakukan adalah mengintegrasikan Arduino Board dengan Labview sehingga dapat terbentuk media pembelajaran sistem kendali dengan objek yang dikendalikan adalah kecepatan motor DC dengan menggunakan sensor Incremental Rotary Encoder yang dapat dipergunakan untuk mengukur kecepatan dan posisi dari motor DC. Arduino Board bertugas membaca pulsa dari sensor yang selanjutnya di konversi ke besaran kecepatan putar dan dikirimkan ke Labview dengan menggunakan protocol komunikasi serial NI-VISA. Algoritma pengendali $P I D$ dibangun dengan menggunakan PID and Fuzzy Logic Toolkit sehingga dapat dilakukan pengendalian dan pengamatan untuk mengetahui respon kendalian secara realtime di labview [9], model matematis dari kendalian motor DC diperoleh dengan menggunakan metode grafis sehingga diperoleh persamaan differensial orde pertama[10] dengan memberikan masukan sinyal unit step.

\section{Metoda Penelitian}

Penelitian yang dilakukan merupakan penelitian eksperimental dimana dalam tahapan penelitianya dilakukan dua tahapan utama, yaitu : Tahapan perancangan dan tahapan implementasi.

\subsection{Perancangan Sistem Kendali Motor DC}

Tahapan perancangan yang dilakukan dengan mengikuti beberapa bagian, yaitu : 
1. Tahapan Observasi : yaitu tahapan yang dilakukan dengan mengamati dan mempelajari perangkat pembelajaran sistem kendali dengan motor DC yang telah ada seperti modul DC Servo Trainer ED-4400B, modul QNET 2.0 DC Motor Board dari Quanser.

2. Tahapan Studi Pustaka : Tahapan pengumpulan referensi baik berupa buku, jurnal, panduan praktik dan referensi lainya yang terkait dengan penelitian.

3. Rancangan Sistem : Rancangan sistem yang dibangun dalam penelitian ini mengacu pada diagram blok pada Gambar 1.

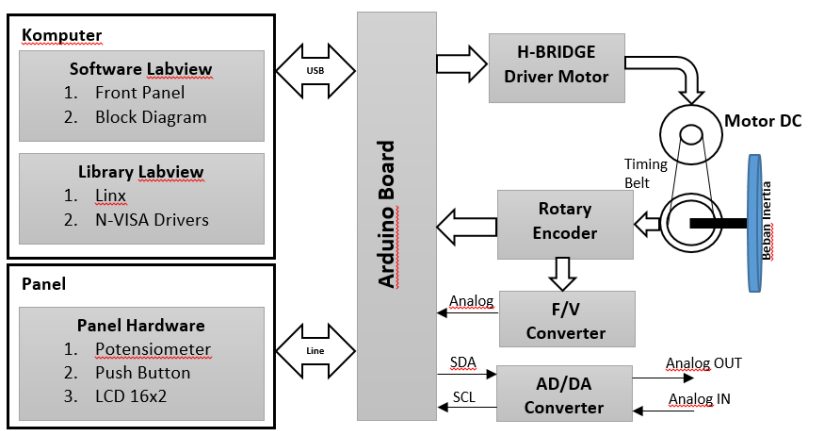

Gambar 1. Diagram Blok Rancangan Sistem Kendali Kecepatan Motor DC dengan Labview.

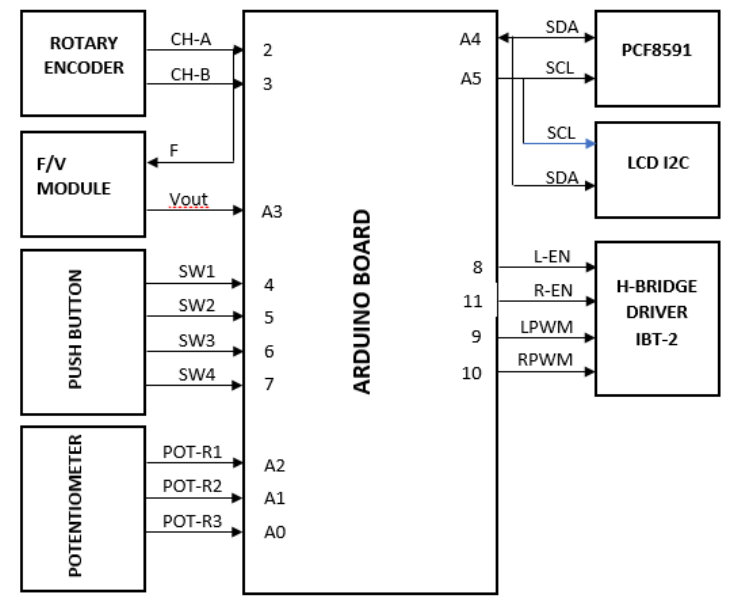

Gambar 2. Diagram Blok Rancangan Koneksi Peripheral dengan Arduino Board.
Sebagai validasi dari pengendali yang dibuat, objek yang dikendalikan adalah motor DC yang turunkan kecepatannya dengan menggunakan timing belt dan pulley yang direncanakan menggunakan pulley tipe 2GT16T pada poros motor DC dan pulley tipe 2GT-60T pada poros beban sekaligus terhubung dengan sensor incremental rotary encoder, adapun rancangan kendalian yang akan dibuat mengacu pada Gambar 2.
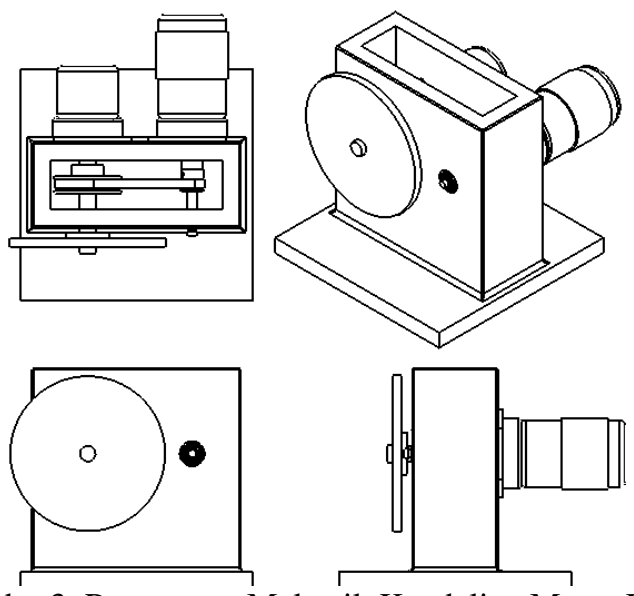

Gambar3. Rancangan Mekanik Kendalian Motor DC

Perancangan yang ditunjukan pada Gambar 1,2 dan 3 merupakan perancangan pada perangkat keras, perancangan perangkat lunak yang dibuat akan diimplementasikan pada arduino board dan program yang dibuat dengan labview, rancangan algoritma sistem dari perangkat lunak mengacu pada Gambar4. 


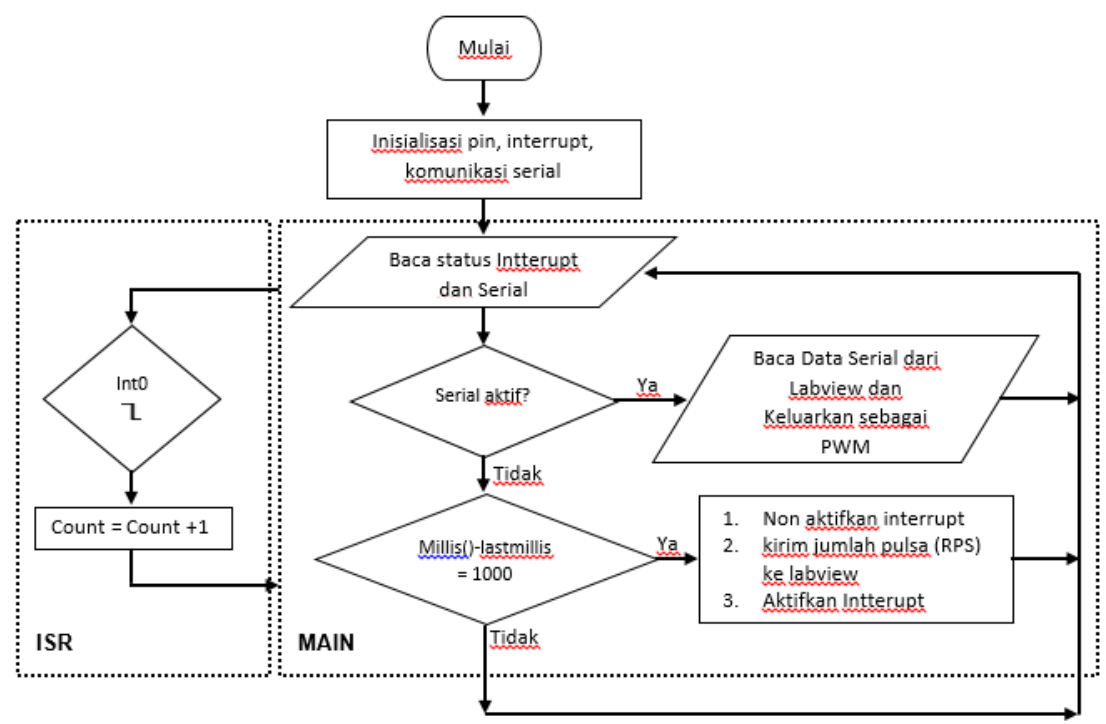

(a) Diagram Alir Program Arduino

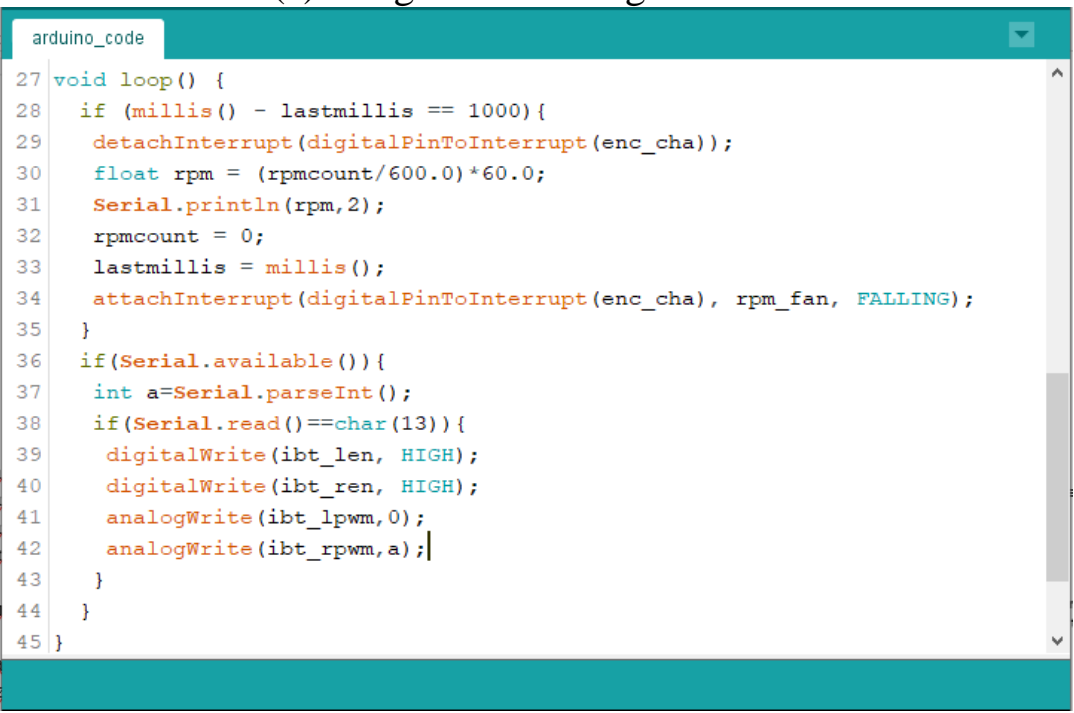

(b) Pseucode Arduino

Gambar4. Diagram Alir dan Pseudocode, (a) Diagram Alir Program Arduino, (b) Main Program Arduino

4. Tahapan Simulasi : Tahapan yang dilakukan dengan mensimulasikan rangkaian elektronika dengan menggunakan perangkat lunak proteus.

\subsection{Tahapan Implementasi Sistem Kendali Motor DC}

Tahapan implementasi yang dilakukan setelah tahapan perancangan diasumsikan sudah memenuhi kebutuhan yang diinginkan, tahapan ini mengikuti beberapa tahapan diantaranya :
1. Tahapan Pengadaan : Tahapan yang dilakukan untuk mengadakan peralatan dan komponen yang dipergunakan dalam pembuatan sistem berdasarkan hasil dari tahapan perancangan.

2. Tahapan Perakitan : Tahapan yang dilakukan dengan merangkai komponen yang telah di adakan untuk tiap bagian dari sistem yang telah dirancang.

3. Tahapan Pengujian : Tahapan pengujian yang dilakukan terhadap sistem yang dibuat, pengujian dilakukan dalam dua tahapan, yaitu pengujian tiap bagian 
yang dilakukan untuk tiap blok sistem dan pengujian keseluruhan sistem untuk mengukur kinerja keseluruhan sistem yang ditelah dibuat berdasarkan hasil perancangan.

\section{Hasil Perancangan}

Berdasarkan tahap perancangan diperoleh bahwa penelitian yang dilakukan adalah membuat sistem kendali kecepatan motor DC, terdapat dua bagian utama yang dibuat, yaitu modul kendalian motor DC dan modul pengendali yang dibangun dengan Labview dan arduino.

\subsection{Hasil Rancangan Kendalian Motor DC}

Berdasarkan hasil perancangan sistem kendali kecepatan motor DC, bagian mekanik yang menjadi objek yang dikendalikan adalah berupa motor DC yang terhubung dengan beban inersia, kecepatan motor DC sebelumnya diturunkan dengan menggunakan timing belt dan timing pulley, sebagaimana ditunjukan pada Gambar 5.

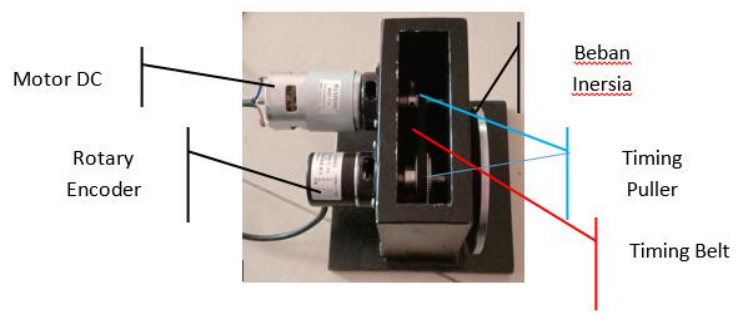

Gambar 5. Hasil Implementasi Sistem Mekanik Motor DC

Pada Gambar5 telah dibuat modul mekanik motor DC, antara motor DC dengan sensor rotary encoder dan beban dihubungkan oleh timing pulley dan belt, poros motor DC menggunakan timing pulley GT2-16T dan porot beban dan rotary encoder menggunakan GT2-60T dan belt GT2-6mm.

\subsection{Hasil Rancangan Perangkat Keras Elektronik \\ Penelitian telah diimplementasikan sistem perangkat keras elektronika yang dipergunakan sebagai perangkat pengendali dari sistem perangkat keras mekanik motor}

DC sehingga dapat bekerja sebagaimana mestinya, hasil dari implementasi dipergunakan beberapa modul elektronika diantaranya adalah, Driver motor DC $\mathrm{H}$ Bridge menggunakan modul IBT-2 dengan IC BTS7960 sebagai komponen penyusun, modul F/V (Frekuensi to voltage) untuk mengkonversi besaran frekuensi $0-1 \mathrm{KHz}$ ke tegangan analog 0-10 Volt DC, potensiometer $20 \mathrm{~K} \Omega$ yang dapat dipergunakan sebagai masukan analog ke arduino board yang dapat dijadikan masukan referensi maupun parameter untuk sinyal kendali, push button sebagai masukan diskrit untuk arduino board sehingga board modul pengendali dapat diimplementasikan secara berdiri sendiri tanpa harus terkoneksi dengan komputer untuk sistem pengendalian, modul selanjutnya adalah modul AD/DA PCF8591 yang merupakan modul konverter analog to digital dan digital to analog yang dapat memfungsikan arduino board terhubung dengan perangkat luar yang menggunakan antarmuka sinyal analog, modul ini dipergunakan pada alat karena pada modul arduino belum mempunyai keluaran sinyal analog serta diharapkan adanya jumlah bit masukan dan keluaran yang sama jumlahnya. Hasil implementasi pengendali yang telah dibuat sebagaimana ditunjukan pada Gambar6.

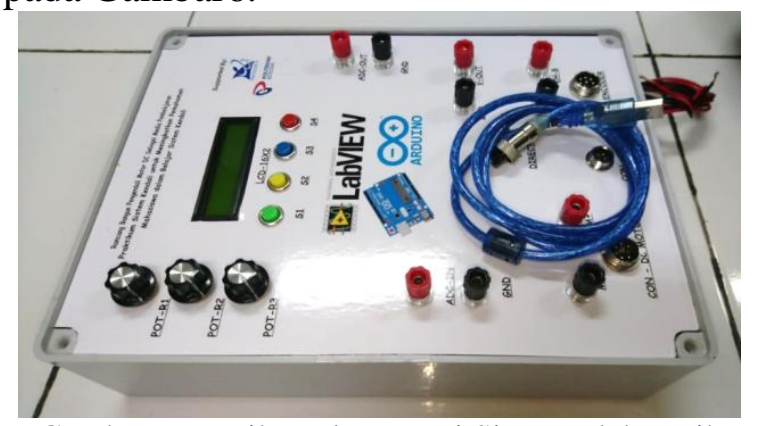

Gambar 6. Hasil Implementasi Sistem Elektronik

Modul yang terdapat pada Gambar6 terhubung semuanya ke board arduino, diagram interkoneksi modul dengan board arduino ditunjukan pada Gambar2. 


\subsection{Hasil Rancangan Perangkat Lunak}

Hasil implementasi perangkat lunak terdapat dua bagian, perangkat lunak yang diimplementasikan pada board arduino dan perangkat lunak pada komputer yang dibangun dengan menggunakan labview, pada penelitian ini perangkat lunak yang diimplementasikan dengan labview adalah pengendali PID yang digunakan untuk mengatur kecepatan motor DC dengan bantuan perangkat keras elektronik, hasil implementasi perangkat lunak dengan labview dapat dilihat pada Gambar 7.
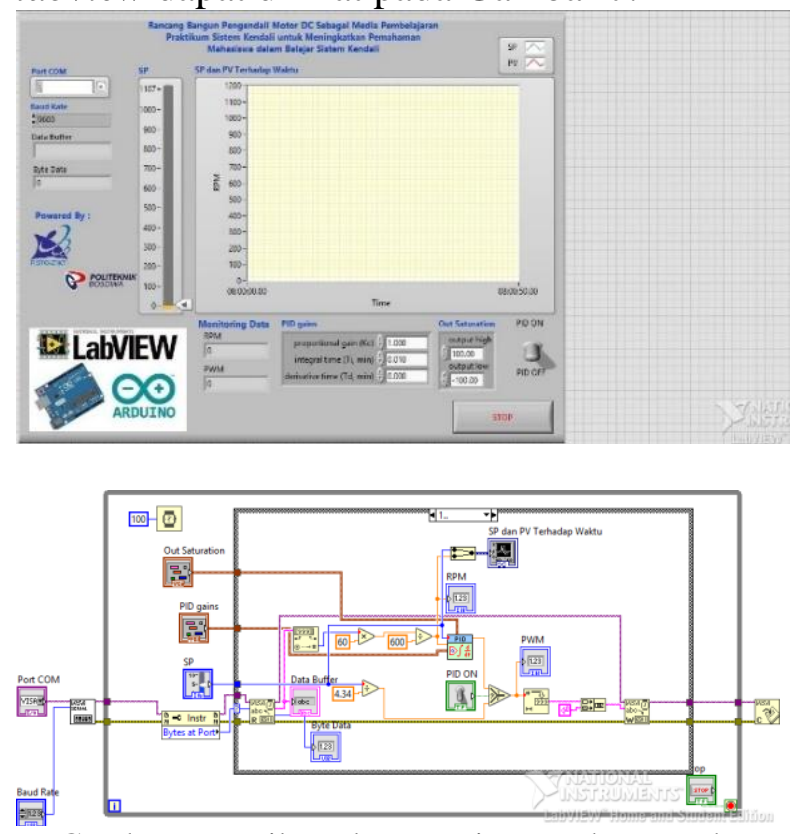

Gambar 7. Hasil Implementasi Perangkat Lunak Labview.

\subsection{Hasil Pengujian}

\subsubsection{Hasil Pengujian Sinyal PWM Motor DC}

Pengujian ini dilakukan untuk mengetahui hubungan nilai PWM terhadap Kecepatan putaran motor, pengujian dilakukan dengan memberikan sinyal PWM kemudian dilakukan pengukuran terhadap tegangan pada kedua pin motor DC dan juga mengukur dengan menggunakan tachometer untuk mengetahui kecepatan motor DC. Hasil pengujian yang dilakukan sebagaimana ditunjukan pada Gambar 8.

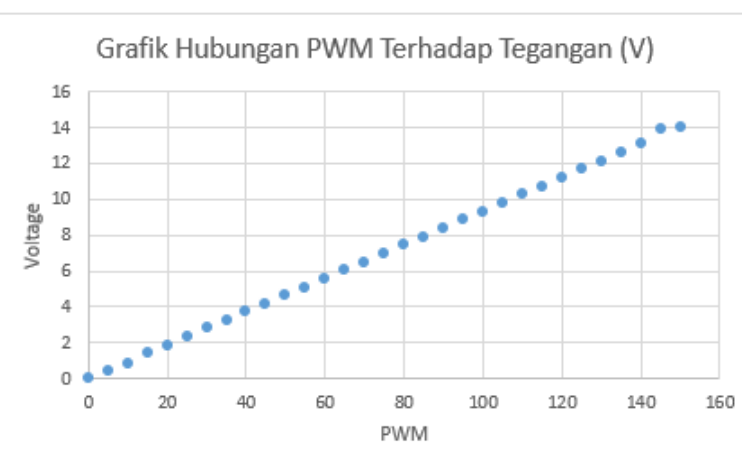

Gambar 8. Hasil Pengujian PWM(8 bit) terhadap Tegangan Motor DC

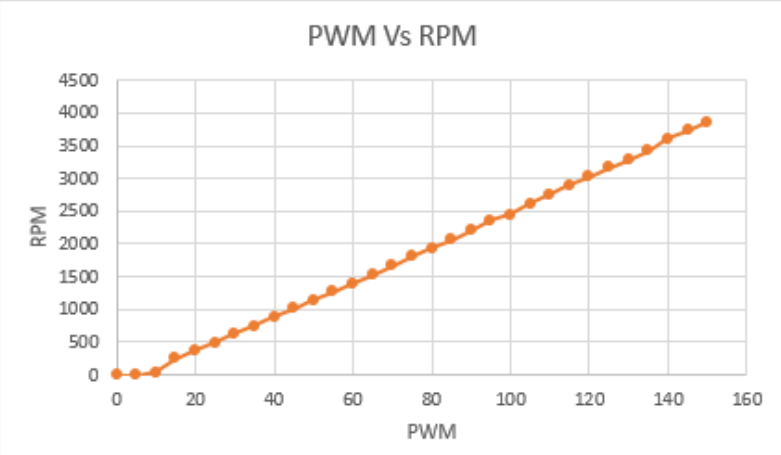

Gambar 9. Hasil Pengujian PWM terhadap Kecepatan Motor

Gambar 8menunjukan bahwa dengan menaikkan nilai PWM diperoleh bahwa nilai tegangan DC pada motor mengalami kenaikan yang linier, pengujian dilakukan dengan memberikan tegangan catu daya $12 \mathrm{Vdc}$ sebagai sumber tegangan dimana berdasarkan datasheet kecepatan maksimum motor adalah 4000RPM, sedangkan pada Gambar 9 menunjukan bahwa ketika arus listrik mengalir menuju kumparan maka torsi akan dibangkitkan melalui kumparan armature dan kumparan medan,dimana torsi dan kecepatan motor berbanding terbalik sehingga semakin tinggi kecepatan motor semakin rendah torsinya maka dalam penelitian ini perangkat mekanik dibuat ratio pulley motor untuk menurunkan kecepatan motor dan menaikkan torsinya. karena motor DC yang digunakan adalah motor DC brushed magnet permanen sebagai pengganti kumparan medan maka magnet permanen akan menyediakan fluks magnet yang konstan, sehingga kecepatan motor merupakan hanya fungsi dari tegangan yang 
diberikan pada kumparan armature. Pada grafik 2 diperlihatkan bahwa pada nilai PWM 10 motor mulai bergerak, hal ini menunjukan bahwa motor DC memerlukan tegangan minimum tertentu untuk mengatasi gesekan mekanis dari sikat, bantalan dan bagian penggerak lainnya untuk memulai putaran. setelah tegangan masukan motor melebihi nilai minimum maka kecepatan motor mulai bergerak linier naik, kelinieran ini juga terjadi gerak lawan dari kumparan armature yang menghasilkan tegangan elektromotif yang menyebabkan pada titik tertentu grafik menjadi datar dikarenakan peningkatan tegangan tidak menyebabkan peningkatan arus listrik, hal ini dikarenakan motor dc yang digunakan merupakan motor DC magnet permanen sehingga kuat medan magnet stator mempunyai kondisi tertentu akan menyebabkan kecepatan motor saturasi.

\subsubsection{Hasil Pengujian Sistem Kendali Kecepatan Motor DC dengan Labview}

Pengujian sistem kendali kecepatan motor, dilakukan untuk mendapatkan dua hasil, yaitu model matematika dari kendalian dan memperoleh nilai parameter pengendali $\mathrm{Kc}$, Ti dan $\mathrm{Td}$ yang menunjukan respon transient paling cepat tanpa terjadi overshoot yang tinggi. Metode yang dipergunakan untuk mendapatkan persamaan karakteristik adalah dengan menggunakan metode grafis, dimana kendalian diberikan masukan berupa sinyal unit step yang selanjutnya diamati respon keluarannya dalam hal ini kecepatan motor, dengan menggunakan persamaan differensial orde pertama nilai konstanta waktu kendalian dapat diperoleh dengan mendapatkan kecepatan $63.2 \%$ dari kecepatan maksimum dan memproyeksikan waktu yang dibutuhkan untuk mencapai kecepatan tersebut.

Pengujian selanjutnya dilakukan sebagai bentuk sistem pengendalian loop tertutup, pengendalian dilakukan untuk mendapatkan parameter pengendalian yang paling optimal, pengendalian dilakukan dengan memasukan nilai setpoint dan dilakukan perubahan parameter pengendalian dengan metode trial and error, metode ini dilakukan awal dengan harapan mahasiswa dapat mengetahui respon sistem ketika parameter $\mathrm{P}$, I, dan D dilakukan perubahan. Hasil pengujian sistem pengendalian dapat dilihat pada Gambar 9 dan Gambar 10.

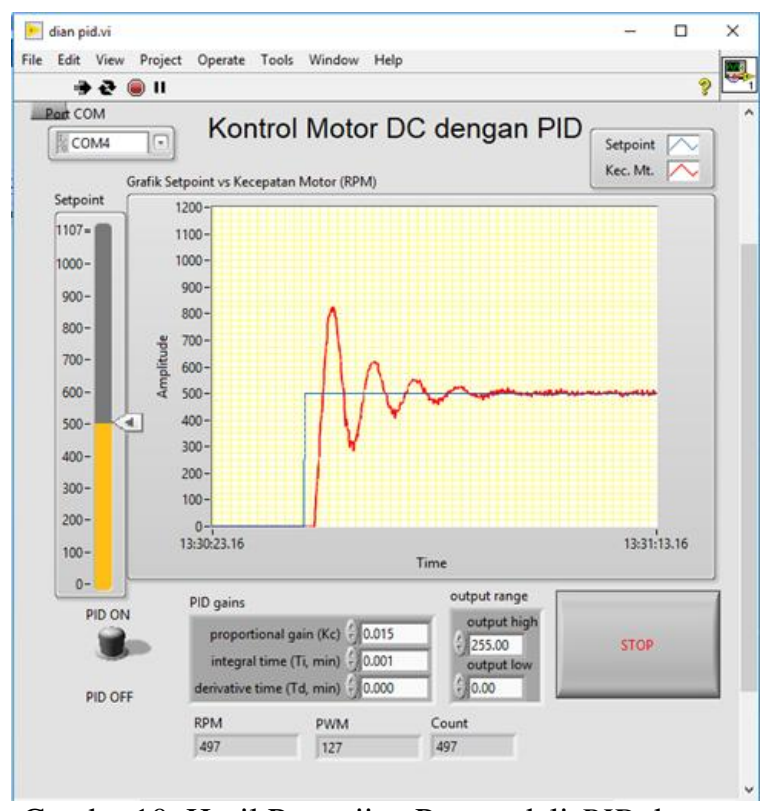

Gambar10. Hasil Pengujian Pengendali PID dengan nilai $\mathrm{Kc}=0.015, \mathrm{Ti}=0.001, \mathrm{Td}=0.000$

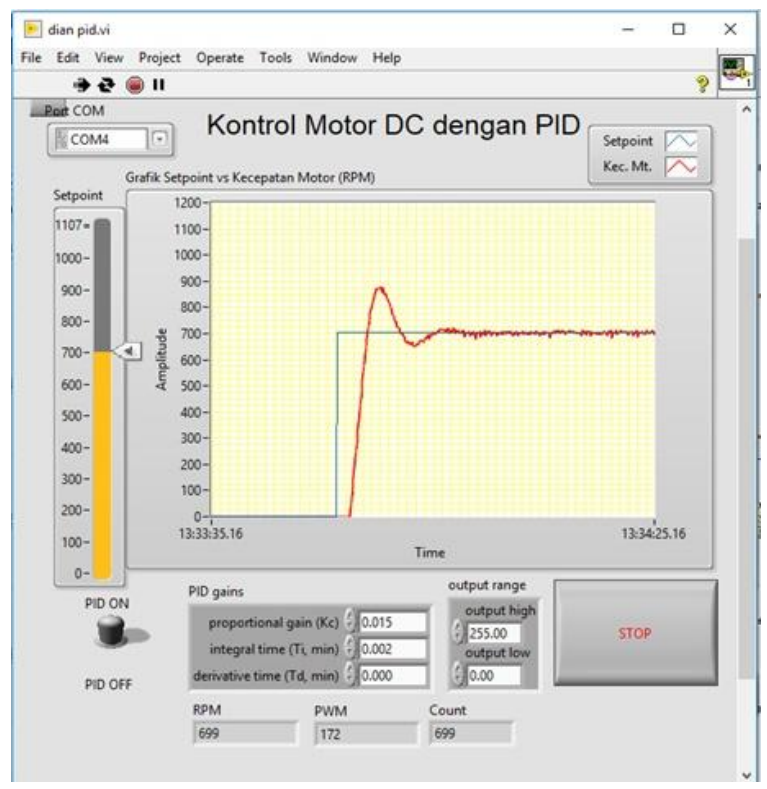

Gambar 11. Hasil Pengujian Pengendali PID dengan nilai $\mathrm{Kc}=0.015, \mathrm{Ti}=0.002, \mathrm{Td}=0.000$ 


\section{Kesimpulan}

Persamaan karakteristik dari mekanik motor DC diperoleh dengan metode grafis dalam bentuk persamaan differensial order pertama.

$$
C_{(s)}=\frac{1250}{0.075 s+1}
$$

Pengendalian Kecepatan Motor DC dengan pengendali $P I D$ diperoleh kondisi terbaik pada $\mathrm{Kc}=0.015, \quad \mathrm{Ti}=0.002$, $\mathrm{Td}=0.000$. pengujian dengan parameter ini dilakukan perubahan kondisi setpoint sebanyak 10 kali perubahan.

\section{Saran}

Dibutuhkan penelitian lebih lanjut terhadap model kendalian motor DC untuk dapat diperoleh persamaan karakteristik yang lebih bagus. Datasheet dari motor DC yang kurang lengkap dapat menjadi penelitian tersendiri mengenai pemodelan matematik mengenai identifikasi parameter sistem fisik dari model kendalian motor DC.

\section{Daftar Pustaka}

[1] J. L. R. and D. L.-C. R. J. -. G. Carlos, "Position control of DC motor through space state for rotary platform," 2017 12th Iber. Conf. Inf. Syst. Technol., pp. 1-6., 2017.

[2] Michael A. Johnson Mohammad H., PID Control New Identification and Design Methods. 2007.

[3] K. R. Asha, S. T. P, R. K. A. V, M. S. S, and K. R. Rekha, "Real Time Speed Control of a DC motor by Temperature Variation using LabVIEW and Arduino," pp. 72-75, 2017.

[4] D. Artanto, Interaksi Arduino dan Labview. Jakarta: PT. Elex Media Komputindo ( Kompas Gramedia ), 2012.

[5] R. Bhavina, N. Jamliya, and K. Vashishtha, "Cascade Control of Dc Motor With Advance," no. 3, pp. 18-20, 2013.

[6] G. Gasparesc, "PID control of a DC motor using Labview Interface for Embedded Platforms," in 2016 12th International Symposium on Electronics and Telecommunications, ISETC 2016 -
Conference Proceedings, 2016, pp. 145148.

[7] A. Visioli, Practical PID Control. 2006.

[8] F. Logic and T. User, "PID and Fuzzy Logic Toolkit User Manual," no. June, 2009.

[9] R. D. Ni, E. D. Ni, and T. E. Ut, "Introduction to LabVIEW for Control Design \& Simulation," Dyn. Control, no. Vi, 2004.

[10] P. V. G. K. Rao, M. V. Subramanyam, and K. Satyaprasad, "Study on PID controller design and performance based on tuning techniques," 2014 Int. Conf. Control. Instrumentation, Commun. Comput. Technol. ICCICCT 2014, no. July, pp. 1411-1417, 2014. 